\title{
PANTHERA FOSSILIS (REICHENAU, 1906) (FELIDAE, CARNIVORA) FROM ZA HÁJOVNOU CAVE (MORAVIA, THE CZECH REPUBLIC): A FOSSIL RECORD FROM 1987-2007
}

\author{
MARTIN SABOL \\ Department of Geology and Palaeontology, Comenius University, Mlynská dolina, SK - 84215 Bratislava, the Slovak Republic; \\ e-mail: sabol@fns.uniba.sk
}

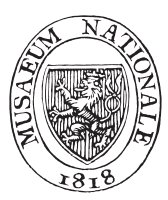

\begin{abstract}
Sabol, M., (2014): Panthera fossilis (Reichenau, 1906) (Felidae, Carnivora) from Za Hájovnou Cave (Moravia, the Czech Republic): a fossil record from 1987-2007. - Acta Mus. Nat. Pragae, Ser. B, Hist. Nat, 70(1-2): 59-70, Praha. ISSN 1804-6479.

Abstract. Based on basic morphometric analysis, 64 fossil remains of lion-like felids from Middle Pleistocene deposits of Za Hájovnou Cave, dated to the period around MIS 9, are attributed to the species Panthera fossilis (REICHENAU, 1906). Within the studied sample, two groups can be preliminarily distinguished. The first group consists of typical representatives of the species, fossils of which were found in cave sediments deposited probably during MIS 9 and/or earlier and their remains corresponds with lion fossils from Château (MIS 13) or Petralona ( $\geq$ MIS 11) from a morphometric point of view. The second group consists of lion fossils from cave deposits dated to the period $\leq$ MIS 9 , belonging to specimens with more advanced characters, indicating a trend towards the characters observed in so called "intermediate forms", especially
\end{abstract} from the Saalian Complex (e. g. from Azé or Wierzchowska Górna).

Panthera fossilis, dental and osteological morphology, evolutionary trends, Middle Pleistocene, Za Hájovnou Cave, Moravia

Received January 20, 2014

Issued October, 2014

\section{Introduction}

The earliest European record of large lion-like felids, attributed to the species Panthera fossilis (ReICHENAU, 1906), is known from the English site of Pakefield, dated within the Marine Isotopic Stratigraphy to MIS 17 stage (680,000 BP) or even to an earlier period (Lewis et al. 2010). The oldest continental record of the species is known from the Italian site of Isernia la Pineta (Sala 1990) with radiometric data $610,000 \pm 10,000 \mathrm{BP}$ and $606,000 \pm 2,000 \mathrm{BP}$ (MIS 15) (García 2003, Argant et al. 2007, Maul et al. 2007).

Within the territory of Moravia, fossil remains of forms which are close relatives of the species $P$. fossilis have been so far described from three sites - Stránská skála, Žernavá, and Za Hájovnou Cave. A part of the assumed Middle Pleistocene (probably Cromerian Complex upper part) lion-like fossils from Stránská skála were originally described by Thenius (1972) as remains of typical Late Pleistocene specimens ( $P$. leo spelaea). The remains of the record from this site according to Thenius (1972) represent a lion-like felid from the Early Pleistocene (P. leo ssp.), whereas Hemmer and Schütt (1969) as well as Hemmer et al. (2001) attributed them to the species P. gombaszogensis. Lion-like fossil remains from Žernavá (Middle Pleistocene, Holsteinian s.1.) were originally described as $P$. spelaea subspec. inc. (Musil 1969) and from Za Hájovnou Cave (Middle Pleistocene, Holsteinian s.l.) as P. cf. mosbachensis and P. cf. spelaea (Ábelová 2005).

The fossil record from all three abovementioned Moravian sites required revision. This was recently realized by detailed morphometric study of former and new lion-like fossils from Za Hájovnou Cave. The preliminary results (an analysis of fossils collected between 1987 to 2007), presented within the scope of this contribution, demostrate certain morphological and size changes in dentition as well as in postcranial elements within the $P$. fossilis lineage during the Middle Pleistocene, indicating the possible importance of the site for understanding the evolution of Pleistocene lion-like felids.

\section{Material and methods}

The fossil material under study was partly discovered during speleological exploration during the 1980s and partly during systematic research at the site which began in 2001. The lion-like fossils were mainly found in fossiliferous deposits of specific cave parts: Vykopaná chodba (= Excavated Corridor, Profile ZH P-3, layers 3 and 4), Kostnice II (= Charnel-House II, Profile ZH P-5, layers 2b to $3 b$ ), Kostnice I (= Charnel-House I, Profile ZH P-6, depth to $4 \mathrm{~m}$ ), Chodba naděje (= Corridor of Hope, Profile ZH P-7b, layers 3-4, and 6), and Narozeninová chodba (= Birthday Corridor, Profile ZH P-9, layer 5) (Text-fig. 1), dated to the period around MIS 9 (Lundberg et al. 2014). Part of the lion-like remains were also found in deposits in the Vařekova chodba (= Vařeka's Corridor). Considering the Late Pleistocene to Holocene age of these deposits, however, the finds from this cave part probably represent a fossil record of a later extinct species, P. spelaea (under revision at present) and are not discussed within the scope of this contribution. In addition, all the finds collected from a non-stratified mound in front of the cave entrance (apart from a fragment of left mandible with $\mathrm{p} 4$ and $\mathrm{m} 1$ ) are 


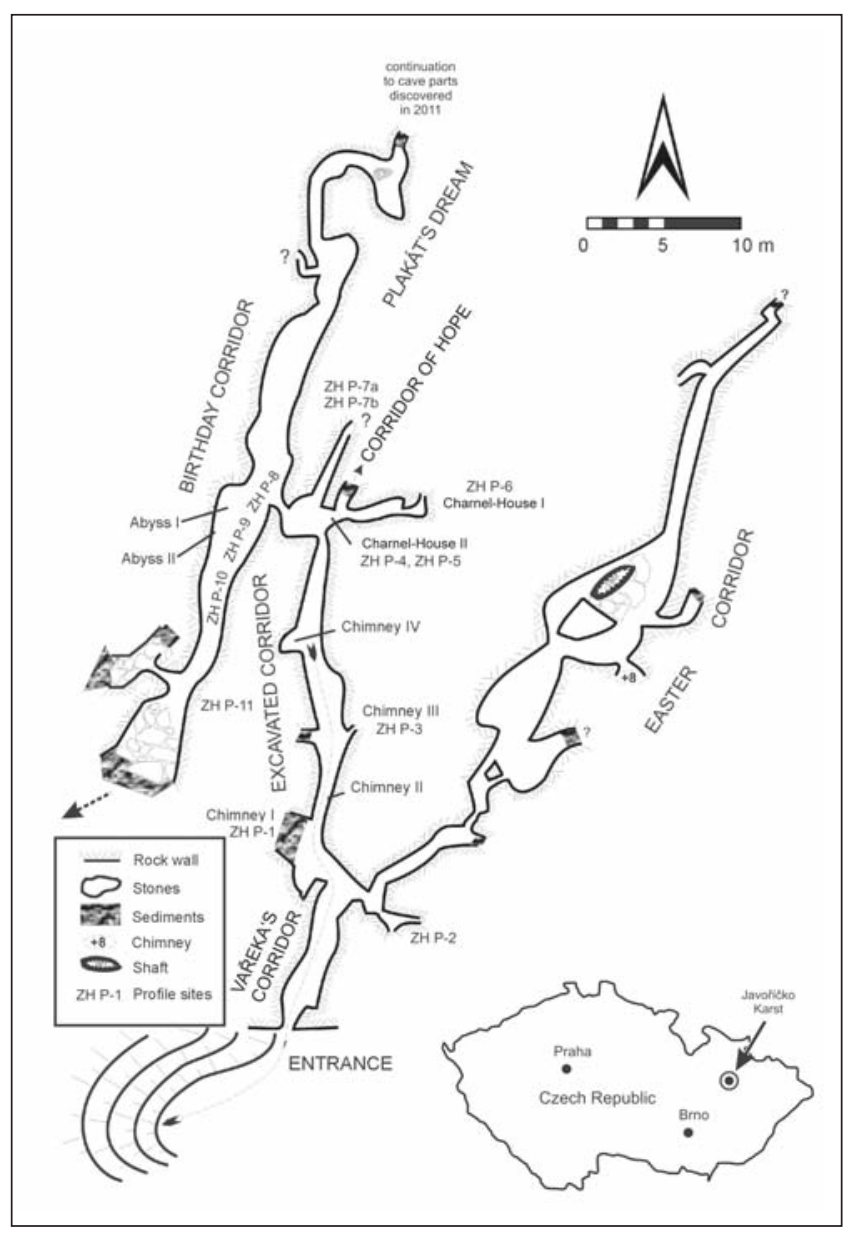

Text-fig. 1. Ground plan of Za Hájovnou Cave (according Tomica, supplemented by Musil, 2005).

excluded from the analysis because of their unclear origin within the cave's sedimentary filling. The fossil material under study (NISP $=64$ ) is stored in the Moravian Land Museum - Anthropos Museum in Brno. It belonged to minimally 4 individuals (MNI).

From the assessed light to yellow-brown teeth, six are still situated in three mandible fragments (two mandible fragments probably belonged to juveniles or subadults). The remainder of the teeth is mostly damaged or are preserved as fragments, partly covered by a very thin surface sinter or sediment cemented by sinter, occasionally with manganese dendrites. All postcranial remains belonged to adult specimens. These frequently remained unbroken, although only 21 fossils are preserved distinctly undamaged. The bones are also yellow-white to yellow-brown, with manganese dendrites. On some bones (such as the vertebra, ulna, astragalus, phalanx and others), marks of biotic taphonomic agent activity (gnawing, chewing, or biting) have been found.

The determination of fossil remains was realized by basic morphometric analysis. Measurements of the studied lion-like finds were made to the nearest $0.01 \mathrm{~mm}$ using digital engineering vernier callipers with a $0.29 \mathrm{~mm}$ standard deviation, $0.08 \mathrm{~mm}$ dispersion, and $2.05 \%$ random error. All measurements are in millimetres. The basic morphological terminology and the measurement-methods for fossils were after Kabitzsch (1960), Vereshchagin (1971), Argant (1991),
Gonzáles (2003), Bona (2006), Barycka (2008), and Christiansen and Harris (2009). Within the text, the upper teeth are referred to by capitals (such as in "P4"), the lower ones by lower case letters (such as in "p4").

\section{Systematic palaeontology}

\section{Family: Felidae Fischer de WALdHEIM, 1817 \\ Subfamily: Pantherinae Pocock, 1917 \\ Genus: Panthera OKen, 1816}

1816

Oken, L., Lehrbuch der Naturgeschichte, Bd. 3, Th. 2, p. 1052.

\section{Species Typica. Panthera pardus (LinNAEUs, 1758)}

Stratigraphic and geographic distribution. Late Pliocene to Recent (MN 16 - MQ 4); Africa, Europe, Asia, North and South America.

Genus characteristics. Big pantherine felids with a shortened viscerocranium, enlarged temporal fosses and orbits, and with wide zygomatic arches (modified according to Argant 1988).

\section{Panthera fossilis (REICHENAU, 1906)}

Text-figs 2-4

1906 Reichenau, W. von, Beiträge zur näheren Kenntnis der Carnivoren aus den Sanden von Mauer und Mosbach. Abh. Großherzogl. Hess. Geol. Landesanst. 4, Darmstadt, p. 301.

2005 P. cf. mosbachensis (DIETRICH) - Ábelová: 172, 174-175, Pl. I/1-2.

2005 P. cf. spelaea (GoLDFuss) - Ábelová: 172, 174-177.

Locus Typicus. Mauer, Germany (MIS 15 or MIS 13).

Stratigraphic and geographic distribution. Middle Pleistocene (MIS 17 - MIS 9/6?), Europe and Asia?

Species characteristics. Large extinct representative of Panthera genus with less specialized lower teeth and less reduced lower premolars. The skull postorbital process is situated more anteriorly and bullae are relatively small and less protuberant. In comparison to P. spelaea, $P$. fossilis possesses smaller incisors; less flattened, but proportionally narrower canines; narrower P2; somewhat narrower P4 with shorter metastyle and smaller parastyle; proportionally shorter main cusps in $\mathrm{P} 3, \mathrm{p} 3$, and $\mathrm{p} 4$; less reduced anterior cusps in premolars; wider $\mathrm{m} 1$; and proportionally longer $\mathrm{p} 4$ from the viewpoint of the $\mathrm{Lm} 1 / \mathrm{Lp} 4$ index. Its skull is slightly wider in the muzzle part and narrower in the postorbital and mastoid part, orbits are relatively smaller, nasals are relatively wider, and bullae are less inflated. Compared to $P$. leo, the species shows a greater overall size, shorter P4 metastyle, and smaller P2 (modified according to Kurtén 1965, Dietrich 1968, Schütt 1969, Schütt and Hemmer 1978, Argant 1988, Baryshnikov and 
Boeskorov 2001, Sotnikova and Nikolskyi 2006, Barycka 2008, and Marciszak et al. 2014).

M a t e ri a l. Vykopaná chodba (left side; age unknown, probably $\leq$ MIS 9) - thoracic vertebra, 2 fragments of radius, Mc III dext., metacarpal fragment, fragment of calcaneus, Mt III sin. fragment, Mt IV sin.? fragment;

Vykopaná chodba (Profile ZH P-3, layers 3 (MIS 9) and 4 (> MIS 9, cold phase) - left astragalus, 2 medial phalanges;

Chodba naděje (Profile ZH P-7b, layer 3; age unknown, probably MIS 9) - fragment of P4 sin.?, m1 dext. fragment, fragment of left ulna, 2 right and 2 left calcanei, Mt IV sin., proximal phalanx, medial phalanx;

Chodba naděje (Profile ZH P-7b, layers 3-4, depth 80-140 cm; age unknown, probably MIS 9) - P4 dext., proximal phalanx;

Chodba naděje (Profile ZH P-7b, layer 4, depth 180-200 $\mathrm{cm}$; age unknown, probably $\geq$ MIS 9) - right astragalus;

Chodba naděje (Profile ZH P-7b, layer 6; age unknown, probably > MIS 9) - m1 dext.;

Kostnice I (Profile ZH P-6, depth to $4 \mathrm{~m}$; age unknown, probably $\geq$ MIS 9) - Mc IV sin.;

Kostnice II (Profile ZH P-5, layer 2b; MIS 9) - fragment of $\mathrm{P} 4$ sin.?, left astragalus;

Kostnice II (Profile ZH P-5, layers 2b-3b; MIS 9) fragment of P4 dext.?;

Kostnice II (Profile ZH P-5, brown loam complex; probably MIS 9) - 2 fragments of right mandible with $\mathrm{p} 4$ and $\mathrm{m} 1$, Mt IV sin.;

Narozeninová chodba (Profile ZH P-9, layer 5; > MIS 9) - C dext., fragment of left mandible with $\mathrm{m} 1$ alveolus, 5 caudal vertebrae, fragment of right scapula, fragment of right humerus, fragment of left humerus, right capitatum, left capitatum, Mc I dext., left patella, fragment of right fibula, fragment of left fibula, right calcaneus, Mt IV dext., fragment of metapodial distal epiphysis, 5 proximal phalanges, 4 medial phalanges, fragments of 2 distal phalanges, sesamoid bone;

Non-stratified finds (exception) - fragment of left mandible with $\mathrm{p} 4$ and $\mathrm{m} 1$.

Description. The right upper canine ( $\mathrm{C}$ dext.) belonged to an adult specimen (Text-fig. $2 \mathrm{a}$ ), according to measurements of the preserved crown part and root probably to a male (Tab. 1). A slightly worn distinct lingual as well as serrated aboral crest is present on the crown. There are also distinguishable grooves on the flattened (lesser than in cave lions) lateral crown sides. In spite of this, the basal crown shape is still oval in cross-section. No basal cingulum is developed.

The crown of the isolated right upper carnassial (P4 dext.) is partly covered by a very thin surface sinter on the protocone lobe (Text-fig. 2b). The dominant robust paracone possesses distinct anterior and posterior crests as well as a distinctly rounded blunt crest on the anterolingual side, running from the cusp tip probably as far as the protocone lobe. In front of the paracone, the crest-shaped parastyle with rounded anteroposterior cutting edge is separated by a notch. The cingular preparastyle (a typical character for P. fossilis) is absent, although the anterior cingular bulge is cuspletshaped (i.e. with the indication of tiny accessory cusps). The slightly damaged metacone is smaller than the parastyle, separated from the paracone by a prominent notch, continuing on the buccal side into a shallow, buccally opening depression with a flat bottom. The metacone continues in a reverse direction via its crest-shaped cutting edge into a rounded metastyle at the posterior crown margin. The metacone - metastyle length is proportionally longer than in the upper carnassials of cave lions (Tab. 1). The cingulum is moderately developed only on the anterobuccal crown margin and indicated on the posterolingual side. From three roots, the posterior root is the most robust and the lingual root under the protocone lobe is the smallest. The rest of the isolated upper fourth premolars, referred to from the site by Ábelová (2005) as 2 P4 sin. and 1 P4 dext., are preserved only as fragments according to the original description. During revision, the presence of these teeth within the fossil record was not validated and also an illustration of one of these specimens (Ábelová 2005: tab. I.1) indicates a rather different tooth type than P4 (P3?).

The anterior cusp (paraconid) of a double-rooted $\mathrm{p} 4$, still situated in a left mandible fragment, is smaller than the posterior one (hypoconid). It possesses a distinctly developed posterior crest and the cusp is separated from the main one (protoconid) by a notch. The main cusp is moderately sloping posteriorly, with a distinctly longer anterior as well as posterior crest. It is more flattened on the buccal side and triangular on the lingual side with a blunt rounded crest-shaped margin. The posterior cusp is also separated from the main cusp by a notch. The cusp possesses a distinct longitudinal crest and it is separated posteriorly by a weak notch from the basal cingulum. This is developed mainly on the posterolingual crown margin, where it is bordering the talonid area. Both notches, separating the main cusp from the paraconid and the hypoconid, pass into shallow valleys on the lingual side. Similar morphology can also be observed in somewhat smaller $\mathrm{p} 4 \mathrm{~s}$ in two right mandible fragments (Tab. 1), differing more or less only in the similar size of the anterior and the posterior cusp, or the slightly smaller hypoconid respectively (see Ábelová 2005: tab. I.2).

The paraconid of an isolated right lower carnassial ( $\mathrm{m} 1$ dext.; Text-fig. 2c) is smaller, but more robust than the protoconid, whereas it is optically lower than the protoconid of $\mathrm{m} 1 \mathrm{sin}$. from the mandible fragment, similarly in a further two $\mathrm{m} 1 \mathrm{~s}$ from right mandible fragments. The paraconid anterior margin is either rounded (isolated $\mathrm{m} 1$ dext.) or oblique and straight, rounding only near the crown base ( $\mathrm{m} 1$ dext. et sin. in situ). The paraconid cutting edge is shorter than the protoconid one. The paraconid is separated from the protoconid by a distinct, relatively deep notch that passes into a wide shallow lingual valley without an accessory cusp at the bottom, or with only an indication of it near the crown base respectively (isolated $\mathrm{m} 1$ dext.). The protoconid possesses distinguishable anterior and posterior margins. The posterior one is nearly vertical, moderately deviated medially at the base (isolated $\mathrm{m} 1$ dext.) or it is sharp, passing into the basal cingulum (or cingular talonid resp.) and bordered by a groove on the inner side (m1 sin. in situ). In the posterior part of the cingular talonid, a tiny cingular cusp may be developed. The cingulum is present only in the posterior crown part or also on the buccal side (isolated $\mathrm{m} 1$ dext.). In the occlusal view, the crown is convexly curved - it is halfmoon-shaped with a distinct cutting edge which forms 


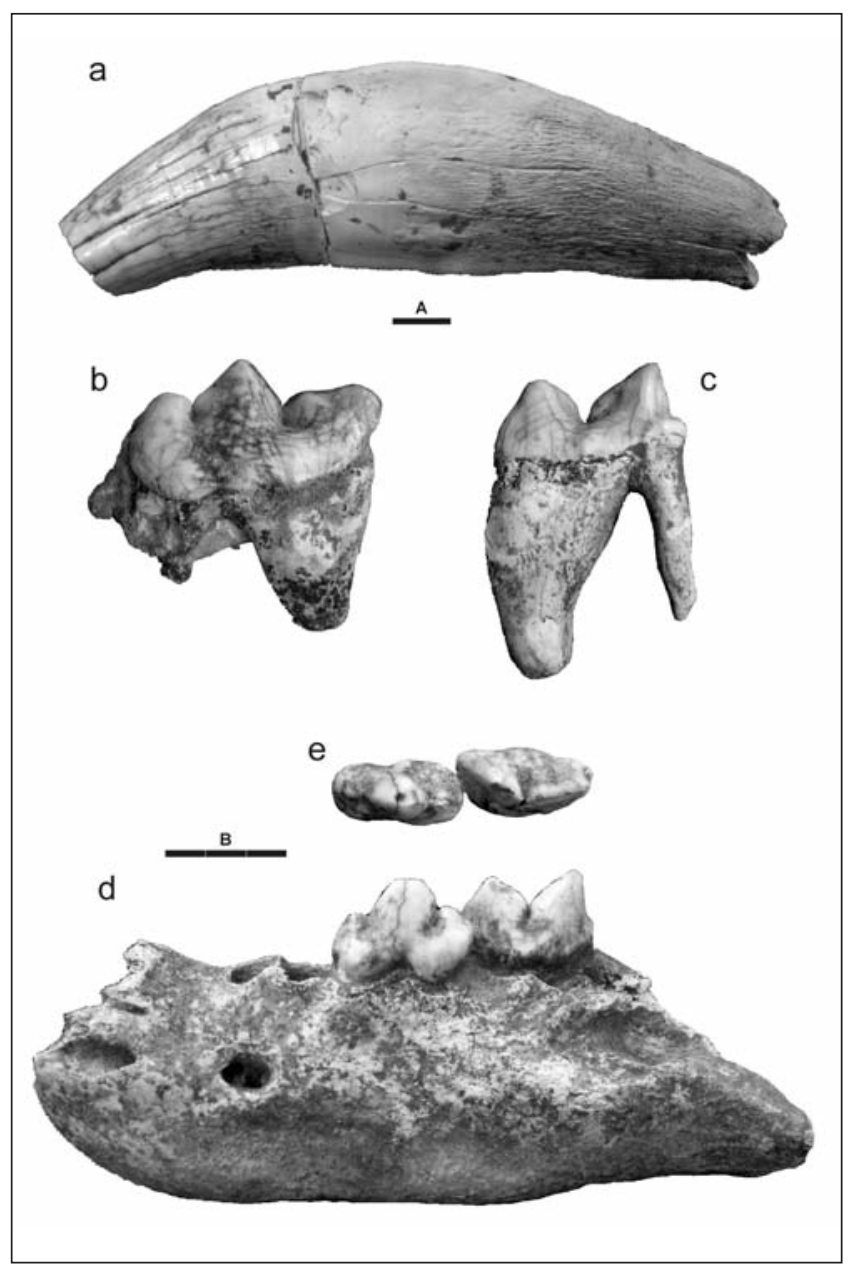

Text-fig. 2. Dentition and mandible of Panthera fossilis (Reichenau, 1906) from Za Hájovnou Cave (Moravia, the Czech Republic), Middle Pleistocene. Scale bars: $A=1 \mathrm{~cm}(\mathrm{a}-\mathrm{c})$, $B=3 \mathrm{~cm}$ (d-e). a - C dext. (Narozeninová chodba, layer 5, > MIS 9), lingual view; $b$ - P4 dext. (Chodba naděje, layer 3-4, MIS 9), buccal view; c - m1 dext. (Chodba naděje, layer 6 , $>$ MIS 9), lingual view; $d$ - left mandible fragment with $p 4$ and $\mathrm{m} 1$ (non-stratified record), buccal view; $\mathrm{e}-\mathbf{a}$ detail occlusal view of $\mathrm{p} 4$ and $\mathrm{m} 1$ of the left mandible.

a relatively wide-open $\mathrm{V}$ in $\mathrm{m} 1$ sin. On the lingual side of all $\mathrm{m} 1 \mathrm{~s}$, a typical bulge can be observed (Text-fig. 2e). A zigzag enamel structure is also present, although this character is variable and its classification value (cf. Schütt and Hemmer 1978 or Barycka 2008) is questionable. Both roots of the isolated right lower carnassial are entirely preserved and the anterior one is more robust as well as larger than the posterior root. A fragment of another isolated $\mathrm{m} 1$ dext. with preserved paraconid and protoconid parts is also known from the site (Ábelová 2005) (Tab. 1).

Mandibles are represented within the fossil record under study only as an unmeasurable left mandible fragment with $\mathrm{m} 1$ alveoli and a left mandible fragment with $\mathrm{p} 4$ and $\mathrm{m} 1$ (described above) and with the alveoli of a canine and two-rooted p3. Both fragments probably belonged to adult males (Text-fig. 2d; Tab. 2). Another two fragments of right mandibles with $\mathrm{p} 4$ and $\mathrm{m} 1$ are figured in the paper by Ábelová (2005: tab. I.2A-B), although only the mandible fragment from tab. I.2B is also briefly described there. The

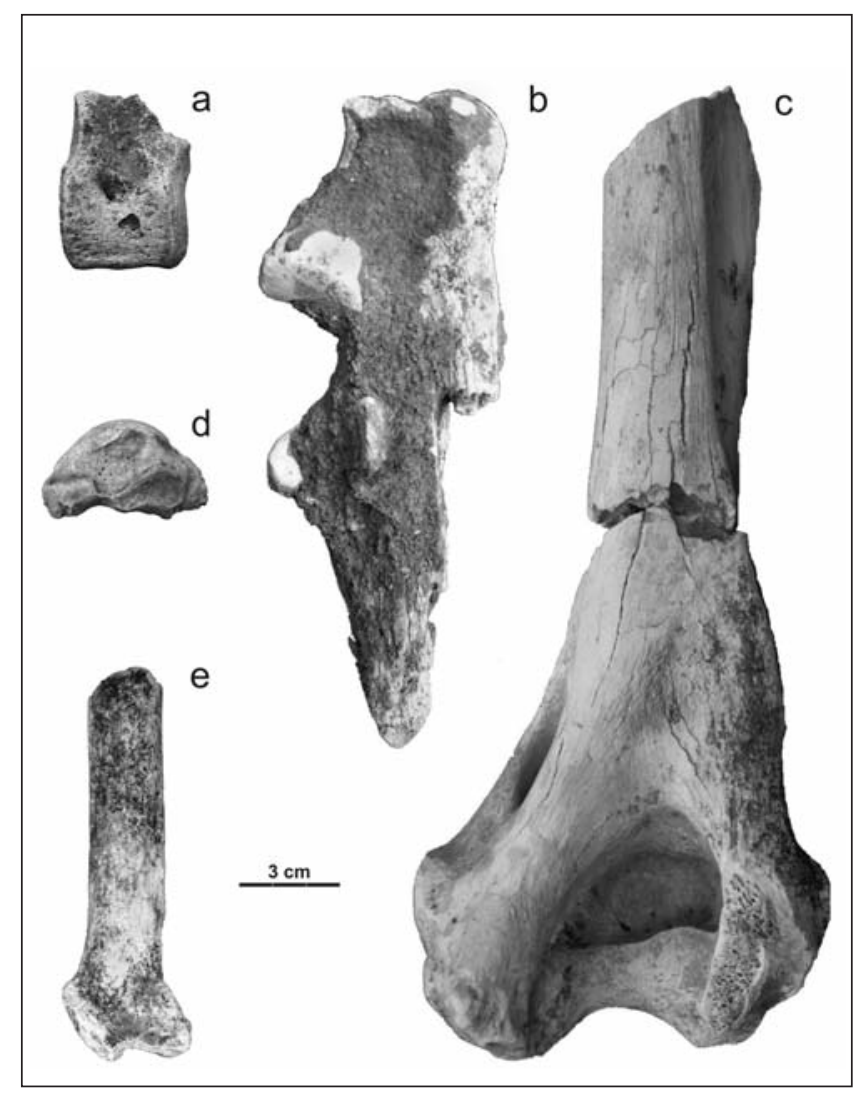

Text-fig. 3. Postcranial fossil record of Panthera fossilis (Reichenau, 1906) from Za Hájovnou Cave (Moravia, the Czech Republic), Middle Pleistocene.

a - thoracic vertebra fragment with biting marks (Vykopaná chodba, left side, $\leq$ MIS 9), lateral view; $b$ - fragment of left ulna (Chodba naděje, layer 3, MIS 9), lateral view; c fragment of right humerus (Narozeninová chodba, layer 5 , > MIS 9), caudal view; d - right capitatum (Narozeninová chodba, layer 5, > MIS 9), lateral view; e - fragment of right Mc III (Vykopaná chodba, left side, $\leq$ MIS 9), dorsal view.

mandible ramus of the adult male (Text-fig. 2d) is relatively high, straight to slightly convex at its base, with three foramina mentalia, the largest of which is situated under the anterior alveolus of $\mathrm{p} 3$ (the remaining two foramens are situated under the diastema between the canine and $\mathrm{p} 3$ ). The preserved anterior part of the masseteric fossa is relatively deep in all mandible finds, extending to under the $\mathrm{m} 1$ protoconid. The diameter of the $\mathrm{p} 3$ anterior alveolus in the adult male mandible fragment is $11.47 \mathrm{~mm} \times 8.72 \mathrm{~mm}$ and the diameter of the $\mathrm{p} 3$ posterior alveolus in the same fragment is $11.52 \mathrm{~mm} \times 11.65 \mathrm{~mm}$.

Based on the so far studied lion-like fossils from $\mathrm{Za}$ Hájovnou Cave, the axial skeleton is represented by only a fragment of thoracic vertebra and five caudal vertebrae from minimally two adults. Interestingly, the body of the thoracic vertebra fragment shows some biting marks of a larger predator/scavenger (Text-fig. 3a), probably a hyena (Crocuta crocuta ssp.) or wolf (Canis lupus ssp.), fossils of which were also found at the site (Ábelová 2005). It can not be excluded that this bone damage could have been caused by another carnivore, such as a bear or specimen of the same species (interspecific or intraspecific conflict?). 
Table 1. Measurements of upper and lower dentition of Panthera fossilis (REICHENAU, 1906) from Za Hájovnou Cave (Moravia, the Czech Republic), Middle Pleistocene (partly according to Ábelová 2005). Measurements in mm, indexes in \%.

\begin{tabular}{|c|c|c|c|c|c|c|c|}
\hline Panthera fossilis, Za Hájovnou Cave & \begin{tabular}{|c|} 
C dext. \\
Narozeni- \\
nová chodba \\
layer 5 \\
$>$ MIS 9 \\
\end{tabular} & $\begin{array}{l}\text { P4 dext. } \\
\text { Chodba } \\
\text { naděje } \\
\text { layers 3-4 } \\
\sim \text { MIS } 9\end{array}$ & $\begin{array}{l}\text { p4 dext. } \\
\text { Kostnice II } \\
\text { brown } \\
\text { loam com. } \\
\text { MIS } 9\end{array}$ & $\begin{array}{l}\text { p4 sin. } \\
\text { non- } \\
\text { stratified } \\
\text { finds }\end{array}$ & $\begin{array}{c}\text { m1 dext. } \\
\text { Chodba } \\
\text { naděje } \\
\text { layer } 6 \\
\text { > MIS } 9\end{array}$ & $\begin{array}{l}\text { m1 dext. } \\
\text { Kostnice II } \\
\text { brown } \\
\text { loam com. } \\
\text { MIS } 9\end{array}$ & $\begin{array}{l}\text { m1 sin. } \\
\text { non- } \\
\text { stratified } \\
\text { finds }\end{array}$ \\
\hline total tooth length & - & 41.70 & 31.00 & 32.86 & 32.45 & 29.61 & 34.33 \\
\hline longitudinal diameter of crown base & 31.10 & - & - & - & - & - & - \\
\hline transversal diameter of crown base & 22.80 & - & - & - & - & - & - \\
\hline $\begin{array}{l}\text { longitudinal diameter of crown base in } \% \\
\text { of transversal diameter of crown base }\end{array}$ & 73.31 & - & - & - & - & - & - \\
\hline paracone length & - & 15.90 & - & - & - & - & - \\
\hline paracone length_ $100 /$ total tooth length & - & 38.13 & - & - & - & - & - \\
\hline metacone - metastyle length & - & 16.90 & - & - & - & - & - \\
\hline metacone - metastyle length $\times 100$ / total tooth length & - & 40.53 & - & - & - & - & - \\
\hline metacone - metastyle length $\times 100 /$ paracone length & - & 106.29 & - & - & - & - & - \\
\hline paracone - metastyle length & - & 30.50 & - & - & - & - & - \\
\hline paracone - metastyle length $\times 100$ / total tooth length & - & 73.14 & - & - & - & - & - \\
\hline paraconid length & - & - & - & 5.61 & 16.50 & - & 16.99 \\
\hline protoconid length & - & - & - & 15.53 & 15.50 & - & 17.73 \\
\hline hypoconid length & - & - & - & 6.81 & - & - & - \\
\hline maximum tooth width & - & - & 15.92 & 16.90 & 17.20 & 16.80 & 17.23 \\
\hline maximum tooth width $\times 100 /$ total tooth length & - & - & 51.36 & 51.43 & 53.01 & 56.74 & 50.19 \\
\hline maximum anterior tooth width & - & - & - & 14.52 & - & - & - \\
\hline maximum anterior tooth width $\times 100$ / total tooth length & - & - & - & 44.19 & - & - & - \\
\hline maximum tooth width in the middle & - & - & - & 16.47 & - & - & - \\
\hline maximum posterior tooth width & - & 13.70 & - & 15.65 & - & - & - \\
\hline maximum posterior tooth width $\times 100 /$ total tooth length & - & 32.85 & - & 47.63 & - & - & - \\
\hline paracone height / paraconid height & - & 23.00 & - & 15.01 & 18.40 & - & 19.82 \\
\hline protoconid height & - & - & 17.00 & 18.24 & 16.30 & 16.69 & 19.68 \\
\hline hypoconid height & - & - & - & 17.24 & - & - & - \\
\hline lower height of the notch in $\mathrm{m} 1$ & - & - & - & - & 10.50 & - & 11.91 \\
\hline $\begin{array}{l}\text { upper height of the notch in } \mathrm{m} 1 \\
(=\text { crown height in the middle })\end{array}$ & - & - & - & - & 13.40 & - & 15.46 \\
\hline length of the paraconid cutting edge & - & - & - & - & 11.00 & - & 10.30 \\
\hline length of the protoconid cutting edge & - & - & - & - & 13.80 & - & 15.01 \\
\hline length between tips of the paraconid and the protoconid & - & - & - & - & 21.50 & - & 20.54 \\
\hline maximum longitudinal diameter of the root & 34.30 & - & - & - & - & - & - \\
\hline maximum transversal diameter of the root & 24.40 & - & - & - & - & - & - \\
\hline $\begin{array}{l}\text { max. longitudinal diameter of the root in } \% \\
\text { of max. longitudinal diameter }\end{array}$ & 71.14 & - & - & - & - & - & - \\
\hline
\end{tabular}

Table 2. Measurements of the left mandible fragment of Panthera fossilis (REICHENAU, 1906) from Za Hájovnou Cave (Moravia, the Czech Republic), Middle Pleistocene. Measurements in $\mathrm{mm}$.

\begin{tabular}{|l|c|}
\hline \multicolumn{1}{|c|}{$\boldsymbol{P}$. fossilis, Za Hájovnou Cave } & $\begin{array}{c}\text { mandibula sin. } \\
\text { non-stratified finds }\end{array}$ \\
\hline depth ramus at diastema & 57.98 \\
\hline depth ramus at p3 anterior margin & 57.42 \\
\hline depth ramus at $\mathrm{p} 4$ anterior margin & 56.53 \\
\hline depth ramus at $\mathrm{m}$ 1 anterior margin & 62.65 \\
\hline depth ramus at m1 posterior margin & 60.49 \\
\hline p3-m1 length (alveolar) & 87.16 \\
\hline p4 length & 32.86 \\
\hline m1 length & 34.33 \\
\hline
\end{tabular}

The preserved scapula fragment of an adult is relatively damaged, e.g. in the middle characteristically cut out glenoid cavity with a transverse dimension (the height) of $55 \mathrm{~mm}$.

The forelimb stylopodium is represented within the fossil record under study by only a fragment of right humerus distal part (Text-fig. 3c; Tab. 3) with the possible marks of biotic agent activity as well as a fragment of left humerus distal epiphysis. Both stylopodial fragments belonged to adult animals. The olecranon fossa of the right humerus is lengthwise, relatively small, but deep and sharply bordered at its base.

From the forelimb zeugopodial region, only a left ulna fragment and fragments of the proximal part of a right and left radius were found within the stratified collecting areas until 2007. The left ulna fragment of an adult specimen (Text-fig. 3b; Tab. 3) consists of the proximal part, mostly covered by a thin sinter layer. A preserved irregular to stepped fracture indicates bone disintegration "after its drying" during the fossilization process, whereas tiny gnawing marks indicate the activity of lesser carnivores (mustelids?) after the animal's death. The oval-shaped heads of both preserved proximal parts of adult radii (caput radii) are slightly narrowed posteriorly and without a sagittal crest. A tuberositas radii on the posterolateral side is less distinguishable than the distinct oval to longitudinal one on 
Table 3. Measurements of forelimb bones of Panthera fossilis (ReichenAu, 1906) from Za Hájovnou Cave (Moravia, the Czech Republic), Middle Pleistocene. Measurements in mm.

\begin{tabular}{|c|c|c|c|c|c|c|c|c|}
\hline Panthera fossilis, Za Hájovnou Cave & $\begin{array}{c}\text { humerus } \\
\text { dext. } \\
\text { Narozeni- } \\
\text { nová ch. } \\
\text { layer } 5 \\
\text { > MIS } 9\end{array}$ & $\begin{array}{c}\text { ulna sin. } \\
\text { Chodba } \\
\text { naděje } \\
\text { layer } 3 \\
\text { MIS } 9\end{array}$ & $\begin{array}{r}\begin{array}{r}\text { radius } \\
\text { dext. }\end{array} \\
\text { Vykop } \\
16 \\
?\end{array}$ & $\begin{array}{l}\text { radius sin. } \\
\text { á chodba } \\
\text { side } \\
\text { IS } 9\end{array}$ & $\begin{array}{l}\text { os carps } \\
\text { III dex } \\
\text { Naroze }\end{array}$ & $\begin{array}{l}\text { S carpale } \\
\text { III sin. } \\
\text { á chodba } \\
5 \\
9\end{array}$ & $\begin{array}{c}\text { Mc I dext. } \\
\text { Narozeni- } \\
\text { nová ch. } \\
\text { layer } 5 \\
\text { > MIS } 9\end{array}$ & $\begin{array}{c}\text { Mc III } \\
\text { dext. } \\
\text { Vykopaná } \\
\text { chodba } \\
\text { left side } \\
\text { ? MIS } 9\end{array}$ \\
\hline height of the sigmoid cavity & - & 47.4 & - & - & - & - & - & - \\
\hline maximum width of the sigmoid cavity & - & 49.0 & - & - & - & - & - & - \\
\hline $\begin{array}{l}\text { maximum anteroposterior diameter } \\
\text { of the olecranon }\end{array}$ & - & 68.4 & 50.1 & 50.5 & - & - & - & - \\
\hline maximum transversal diameter of the olecranon & - & 34.2 & - & - & - & - & - & - \\
\hline $\begin{array}{l}\text { maximum anteroposterior diameter } \\
\text { of the proximal epiphysis }\end{array}$ & - & - & - & - & - & - & - & 38.7 \\
\hline $\begin{array}{l}\text { maximum transversal diameter } \\
\text { of the proximal epiphysis }\end{array}$ & - & - & - & - & - & - & - & 35.2 \\
\hline height of the anterior apophysis of the olecranon & - & 69.5 & - & - & - & - & - & - \\
\hline anteroposterior diameter of the neck & - & - & 34.9 & 35.0 & - & - & - & - \\
\hline $\begin{array}{l}\text { anteroposterior diameter of the proximal } \\
\text { articular surface }\end{array}$ & - & - & 39.4 & 47.3 & - & - & - & - \\
\hline anteroposterior diameter of the diaphysis & - & - & 41.8 & - & - & - & 17.6 & 19.1 \\
\hline transversal diameter of the diaphysis & - & - & - & - & - & - & 21.5 & 21.0 \\
\hline transversal diameter of the diaphysis (distal) & 57.8 & - & - & - & - & - & - & - \\
\hline anteroposterior diameter of the diaphysis (distal) & 44.4 & - & - & - & - & - & - & - \\
\hline upper transversal diameter of the trochlea & 69.2 & - & - & - & - & - & - & - \\
\hline lower transversal diameter of the trochlea & 75.2 & - & - & - & - & - & - & - \\
\hline maximum height of the trochlea & 43.7 & - & - & - & - & - & - & - \\
\hline maximum width of the olecranon fossa & 44.8 & - & - & - & - & - & - & - \\
\hline $\begin{array}{l}\text { anteroposterior diameter of the distal epiphysis } \\
\text { at the place of the trochlea }\end{array}$ & 34.9 & - & - & - & - & - & - & - \\
\hline $\begin{array}{l}\text { maximum anteroposterior diameter } \\
\text { of the distal epiphysis }\end{array}$ & - & - & - & - & - & - & 21.4 & - \\
\hline $\begin{array}{l}\text { maximum transversal diameter } \\
\text { of the distal epiphysis }\end{array}$ & - & - & - & - & - & - & 22.5 & - \\
\hline maximum transversal diameter & - & - & - & - & 29.0 & 28.6 & - & - \\
\hline maximum anteroposterior diameter & - & - & - & - & 30.2 & 33.3 & - & - \\
\hline maximum vertical diameter & - & - & - & - & 48.6 & 46.6 & - & - \\
\hline
\end{tabular}

the medial (inner) side. The inner surface of the diaphysis is flat to convex, bordered posteriorly by a distinctly rough crest and by a smaller oblique one in the middle. The diaphyseal lateral surface is moderately concave and the diaphysis is enlarged in a downwards direction.

The right and left capitatum of adult individuals (Text-fig. 3d; Tab. 3) are preserved almost undamaged, without pathological characters and postmortal traces of taphonomic agents.

Metacarpals are represented within the fossil record under study only by a fragment of Mc I dext. distal part and Mc III dext. proximal region (Text-fig. 3e) both from adult animals (Tab. 3) as well as by a fragment of undetermined metacarpal bone. Ábelová (2005) also mentioned a find of Mc IV sin. distal epiphysis from Middle Pleistocene deposits from this site.

The hindlimb skeleton is represented within the studied sample of fossil remains by a left patella, right and left fibula, as well as by tarsal and metatarsal bones (Text-fig. 4).

The damaged left patella with maximum longitudinal diameter $32.5 \mathrm{~mm}$ belonged to an adult, similarly the distal part of a left fibula with preserved distal epiphysis with maximum transversal diameter $35.6 \mathrm{~mm}$ and with diaphyseal part, showing a columnar fracture. The unmeasurable fragment of the left fibula consists only of its distal epiphysis.
From tarsal bones, only a right calcaneus and right astragalus have been studied. The damaged right calcaneus from Narozeninová chodba belonged to a smaller adult (female?) (Tab. 4). From a morphological viewpoint, it shows a greater similarity with the calcaneus of $P$. spelaea than with that of $P$. leo. Its anterior and central astragal facets (facies articularis talaris anterior et media) are separated, or are connected only by a narrow crest-shaped element respectively. These astragal facets are frequently separated in calcaneal bones of cave lion, whereas those of modern lion are connected by a distinct longitudinal facet. Ábelová (2005) also mentioned a record of another two right and two left calcaneal bones of adult specimens from layer 3 of the Chodba naděje. She identified these bones with calcaneal bones of $P$. spelaea from a morphological viewpoint, but attributed them to more robust specimens rather than lionlike felids from the Last Glacial on the basis of their measurements.

The right astragalus of an adult specimen from the Chodba naděje (Tab. 4) shows marks of taphonomic agent activity (gnawing?) on the bone head. A further two left astragali were found in the Kostnice II (Profile ZH P-5, layer 2b) and the Vykopaná chodba (Profile ZH P-3, layers 4) (Ábelová 2005). 


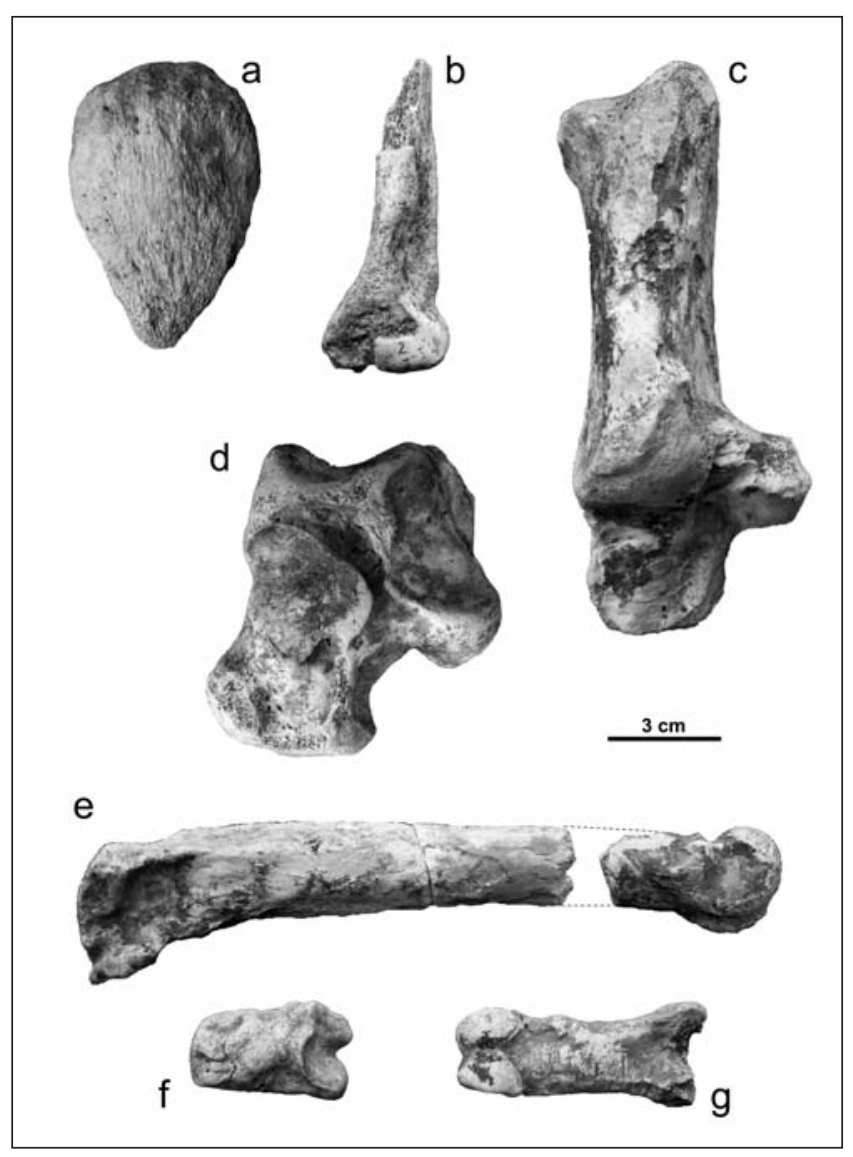

Text-fig. 4. Hindlimb bones of Panthera fossilis (REICHENAU, 1906) from Za Hájovnou Cave (Moravia, the Czech Republic), Middle Pleistocene.

a - left patella (Narozeninová chodba, layer 5, > MIS 9), anterior view; $b$ - fragment of left fibula (Narozeninová chodba, layer 5, > MIS 9), anterior view; c - right calcaneus (Narozeninová chodba, layer 5, > MIS 9), dorsal view; d - right astragalus (Chodba naděje, layer 4, $\leq$ MIS 9), distal end view; e - left Mt IV (Narozeninová chodba, layer 5, > MIS 9), medial view; f - proximal phalanx of the first digit (Narozeninová chodba, layer 5, > MIS 9), dorsal view; $g$ - proximal phalanx with gnaw marks (Narozeninová chodba, layer 5, > MIS 9), plantar view.

Only a fragment of the adult left Mt III proximal part with irregular transversal fracture is preserved within the studied sample (Tab. 4). On the contrary, Mt IV is represented by three specimens (one right and two left) and probably also by a fragment (Tab. 4). The adult Mt IV dext. is damaged on the surface. Its distal part is broken off (V-shaped fracture, see below). Mt IV sin. from layer 3 of the Chodba naděje, covered by a sinter layer, belonged probably to a relatively large individual (the total bone length is approximatly $151 \mathrm{~mm}$ ). Also Mt IV sin. from the brown loam complex of the Kostnice II is identically robust. This metatarsal bone is similar to Mt IV of P. spelaea from the morphological viewpoint, but its measurements exceed those of cave lion (Ábelová 2005). A Mt IV sin. (?) fragment consists of only the diaphysis and the distal part.

Phalanges represent the most frequent element of lion-like fossils within the sample under study. There are 7 proximal (one of these belongs to a first left digit, Text-fig. 4f), 7 medial (with basal exostosis in one case), and 2 distal phalanges, which are preserved only fragmentarily. All phalanges belonged to adults. Gnawing marks of a rodent are distinguishable on one proximal phalanx (Text-fig. 4g).

From other lion-like bones, a nearly undamaged adult sesamoid bone, a calcaneus fragment as well as a fragment of the metapodial distal epiphysis, probably belonging to the above described Mt IV dext., were determined.

\section{Discussion}

The fossil finds of lion-like felids from Middle Pleistocene deposits of $\mathrm{Za}$ Hájovnou Cave suggest relatively big specimens, corresponding in size to close relatives from other European sites with a Middle Pleistocene fossil record. This size similarity is observable mainly in fossil dental remains as well as in the complete bones.

The upper canine from layer 5 of the Narozeninová chodba is very similar to canines from the French site of Azé (an "intermediate form" Panthera fossilis - spelaea) from the viewpoint of crown measurements. It is, however, more slight when compared with a large $P$. fossilis canine from Leynes, another Middle Pleistocene French site. On the other hand, it is more robust than the lion upper canine from the Holsteinian site of Lunel Viel (cf. Bonifay 1971: p. 304, fig. 72). In general, the canine from the Moravian site is also larger and more robust than the upper canines of cave lions (P. spelaea) from the Late Pleistocene, but differing from these in its less laterally flattened crown.

The morphology of the isolated P4 dext., found in the Chodba naděje (layer 3-4), shows typical characters of the species $P$. fossilis, such as the absence of preparastyle or the relatively short metacone, although the posterior metaconemetastyle cutting edge is longer than the paracone.

Sizewise, this upper carnassial is relatively larger than the P4s from Château (P. fossilis) and Azé (Argant 1991), it also distinctly exceeds the upper carnassials from Stránská skála (Thenius 1972), Vértesszőlős II and Solymár (Hankó 2007) or those from the southern European sites of Isernia la Pineta (Sala 1990) and Sima de los Huesos (García 2003). Larger P4s are known for example from Wierzchowska Górna (Wojtusiak 1953) as well as in the Mauer skull (Wurm 1912) and they can also be present in large male cave lions from the Last Glacial (such as the cave lion male from Medvedia Cave in the Western Tatras in Slovakia).

In their measurements, the $\mathrm{p} 4 \mathrm{~s}$ correspond with those from Mosbach (P. fossilis), Wierzchowska Górna (Wojtusiak 1953), and Azé (Argant 1991) (Text-fig. 5), although p4 dext. from the Kostnice II is proportionally smaller than $\mathrm{p} 4 \mathrm{sin}$. in the mandible from the non-stratified finds. The paraconid is approximately as large as the hypoconid, or the paraconid (p4 sin.) or the hypoconid (p4 dext.) is somewhat smaller respectively. More robust, but narrower paraconid than the hypoconid can be found in $\mathrm{p} 4 \mathrm{~s}$ of individuals from Stránská skála, attributed by Thenius (1972) to an earlier form of lion-like felid ( $P$. leo subsp. indet.). This character is present also in some specimens from Wierzchowska Górna (Barycka 2008). In later forms, attributed to $P$. spelaea, both cuspids are about the same size and the premolars are proportionally more reduced than those of $P$. fossilis (Schütt and Hemmer 1978, Barycka 2008). A relatively short protoconid is typical 
Table 4. Measurements of hindlimb bones of Panthera fossilis (ReIChenau, 1906) from Za Hájovnou Cave (Moravia, the Czech Republic), Middle Pleistocene (partly according to Ábelová 2005). Measurements in mm.

\begin{tabular}{|c|c|c|c|c|c|c|c|c|c|c|c|}
\hline $\begin{array}{l}\text { Panthera fossilis, } \\
\text { Za Hájovnou Cave }\end{array}$ & $\begin{array}{c}\text { astragalus } \\
\text { dext. } \\
\text { Chodba } \\
\text { naděje } \\
\text { layer } 4 \\
\\
\text { ? MIS } 9\end{array}$ & \begin{tabular}{|c|} 
astragalus \\
sin. \\
Vykopaná \\
chodba \\
layer 4 \\
\\
> MIS 9
\end{tabular} & \begin{tabular}{|c|} 
calcaneus \\
dext. \\
Narozeni- \\
nová ch. \\
layer 5 \\
> MIS 9
\end{tabular} & $\begin{array}{l}\text { calcaneus } \\
\text { dext. }\end{array}$ & $\begin{array}{r}\text { calcaneus } \\
\text { dext. } \\
\text { Chodba } \\
\text { lay } \\
\text { MI }\end{array}$ & $\begin{array}{l}\text { calcaneus } \\
\text { sin. } \\
\text { naděje } \\
\text { er } 3 \\
\text { S } 9\end{array}$ & $\begin{array}{l}\text { calcaneus } \\
\text { sin. }\end{array}$ & $\begin{array}{c}\text { Mt III sin. } \\
\text { Vykopaná } \\
\text { chodba } \\
\text { left side } \\
\text { ? MIS } 9\end{array}$ & $\begin{array}{c}\text { Mt IV } \\
\text { dext. } \\
\text { Narozeni- } \\
\text { nová ch. } \\
\text { layer } 5 \\
\text { > MIS } 9\end{array}$ & $\begin{array}{c}\text { Mt IV sin. } \\
\text { Chodba } \\
\text { naděje } \\
\text { layer 3 } \\
\text { MIS } 9\end{array}$ & $\begin{array}{c}\text { Mt IV } \\
\text { sin. } \\
\text { Kostni- } \\
\text { ce II } \\
\text { brown } \\
\text { loam com } \\
\text { MIS 9 }\end{array}$ \\
\hline maximum transversal diameter & 74.90 & 74.00 & 80.50 & 52.43 & 59.80 & 74.50 & 55.01 & - & - & - & - \\
\hline maximum anteroposterior diameter & 69.70 & 56.24 & 135.20 & 125.90 & 148.10 & 137.80 & 147.10 & - & - & - & 161.00 \\
\hline maximum dorso-plantar diameter & 53.00 & 38.76 & 61.60 & - & - & - & - & - & - & - & - \\
\hline $\begin{array}{l}\text { maximum anteroposterior diameter } \\
\text { of the proximal epiphysis }\end{array}$ & - & - & - & - & - & - & - & - & 40.00 & 33.60 & 33.89 \\
\hline $\begin{array}{l}\text { maximum transversal diameter } \\
\text { of the proximal epiphysis }\end{array}$ & - & - & - & - & - & - & - & 33.60 & 30.60 & 28.50 & 31.80 \\
\hline $\begin{array}{l}\text { transversal diameter of the calcaneal } \\
\text { tuberosity }\end{array}$ & - & - & 46.30 & 34.94 & 44.40 & - & 39.00 & - & - & - & - \\
\hline $\begin{array}{l}\text { anteroposterior diameter } \\
\text { of the diaphysis }\end{array}$ & - & - & - & - & - & - & - & 20.90 & 19.60 & 18.10 & 22.00 \\
\hline transversal diameter of the diaphysis & - & - & - & - & - & - & - & 26.80 & 21.40 & 21.10 & 22.25 \\
\hline $\begin{array}{l}\text { minimum transversal diameter } \\
\text { of the diaphysis }\end{array}$ & - & - & 37.60 & 27.43 & 33.00 & - & 29.44 & - & - & - & - \\
\hline anteroposterior diameter of the trochlea & 56.10 & - & - & - & - & - & - & - & - & - & - \\
\hline transversal diameter of the trochlea & 42.20 & 40.79 & - & - & - & - & - & - & - & - & - \\
\hline $\begin{array}{l}\text { dorso-plantar diameter of the articular } \\
\text { head for os naviculare }\end{array}$ & 30.60 & 33.72 & - & - & - & - & - & - & - & - & - \\
\hline $\begin{array}{l}\text { transversal diameter of the articular } \\
\text { head for os naviculare }\end{array}$ & 43.40 & 36.57 & - & - & - & - & - & - & - & - & - \\
\hline $\begin{array}{l}\text { dorso-plantar diameter of the neck } \\
\text { of the articular head for os naviculare }\end{array}$ & 31.90 & 29.64 & - & - & - & - & - & - & - & - & - \\
\hline $\begin{array}{l}\text { transversal diameter of the neck of the } \\
\text { articular head for os naviculare }\end{array}$ & 34.50 & 31.83 & - & - & - & - & - & - & - & - & - \\
\hline $\begin{array}{l}\text { maximum anteroposterior diameter } \\
\text { of the distal epiphysis }\end{array}$ & - & - & - & - & - & - & - & - & - & 28.10 & 20.77 \\
\hline $\begin{array}{l}\text { maximum transversal diameter } \\
\text { of the distal epiphysis }\end{array}$ & - & - & - & - & - & - & - & - & - & 30.00 & 20.83 \\
\hline $\begin{array}{l}\text { transversal diameter of the distal } \\
\text { epiphysis trochlea }\end{array}$ & - & - & - & - & - & - & - & - & - & 25.90 & 20.50 \\
\hline
\end{tabular}

for $\mathrm{p} 4 \mathrm{~s}$ of Middle Pleistocene lion-like felids (Schütt and Hemmer 1978).

The three lower carnassials in the present study show certain size differences. Whereas isolated $\mathrm{m} 1$ dext. from the Chodba naděje (layer 6) and $\mathrm{m} 1 \mathrm{sin}$. in the mandible fragment from the non-stratified finds are sizewise very similar to big specimens from Château and Petralona (Text-fig. 5), the smaller $\mathrm{m} 1 \mathrm{dext}$. from the mandible fragment found within the brown loam complex of the Kostnice II comes within the size range of $\mathrm{m} 1 \mathrm{~s}$ from Mosbach and Sima de los Huesos (Text-fig. 5) as well as those from Hungarian Middle Pleistocene sites (cf. Hankó 2007: tab. 12). The length of all three teeth, however, come within the size range of $P$. fossilis m1s (Schütt and Hemmer 1978), or (in the case of m1 sin.) exceed it respectively. They are also distinctly wider than $\mathrm{m} 1 \mathrm{~s}$ of $P$. spelaea or those of lion-like felids from the Saalian Complex to the Late Pleistocene (Hemmer 1974, Ballesio 1980). The reduced talonid, the absence of accessory cusps on the lingual side base between the paraconid and the protoconid, as well as the more robust, but lower paraconid are typical characters for lion-like felids from the Middle Pleistocene rather than those from the Late Pleistocene (cf. Thenius 1972: Abb. 12 a 15).

From a size viewpoint, the ratio between the length of $\mathrm{p} 4$ and $\mathrm{m} 1$ within the same mandible fragment, expressed by
Lm1/Lp4 x 100 index, is also interesting. Whereas the index value for the left mandible fragment from non-stratified finds is 104.5 , the index value for the right mandible fragment from the brown loam complex in the Kostnice II is only 95.5. The difference in index values is caused by the greater length of $\mathrm{m} 1$ from the left mandible fragment as well as the greater length of $\mathrm{p} 4$ from the right mandible fragment (Tab. 1), also as in the dentition of a further right mandible fragment (cf. Ábelová 2005: tab. I/2A-B). In both cases, the calculated indices are closer to values for P. fossilis than for P. spelaea, or come even within the range for modern lions (Lehmann 1954). On the other hand, shorter m1s are typical more for lion-like felids from the Middle Pleistocene than for Late Pleistocene cave lions.

From the more or less completely preserved postcranial elements within the sample under study, tarsal bones (astragali and calcanei) and metapodials are of great importantance for interspecific correlation. From the three astragali found, the right astragalus from the Chodba naděje (layer 4) and the left one from the Vykopaná chodba (layer 4) show a size similarity with astragali of $P$. fossilis from Château, whereas another left astragalus, described by Ábelová (2005) from the Kostnice II (layer 2b), is smaller, according to its measurements being within the upper level of the range for astragali of Late Pleistocene 


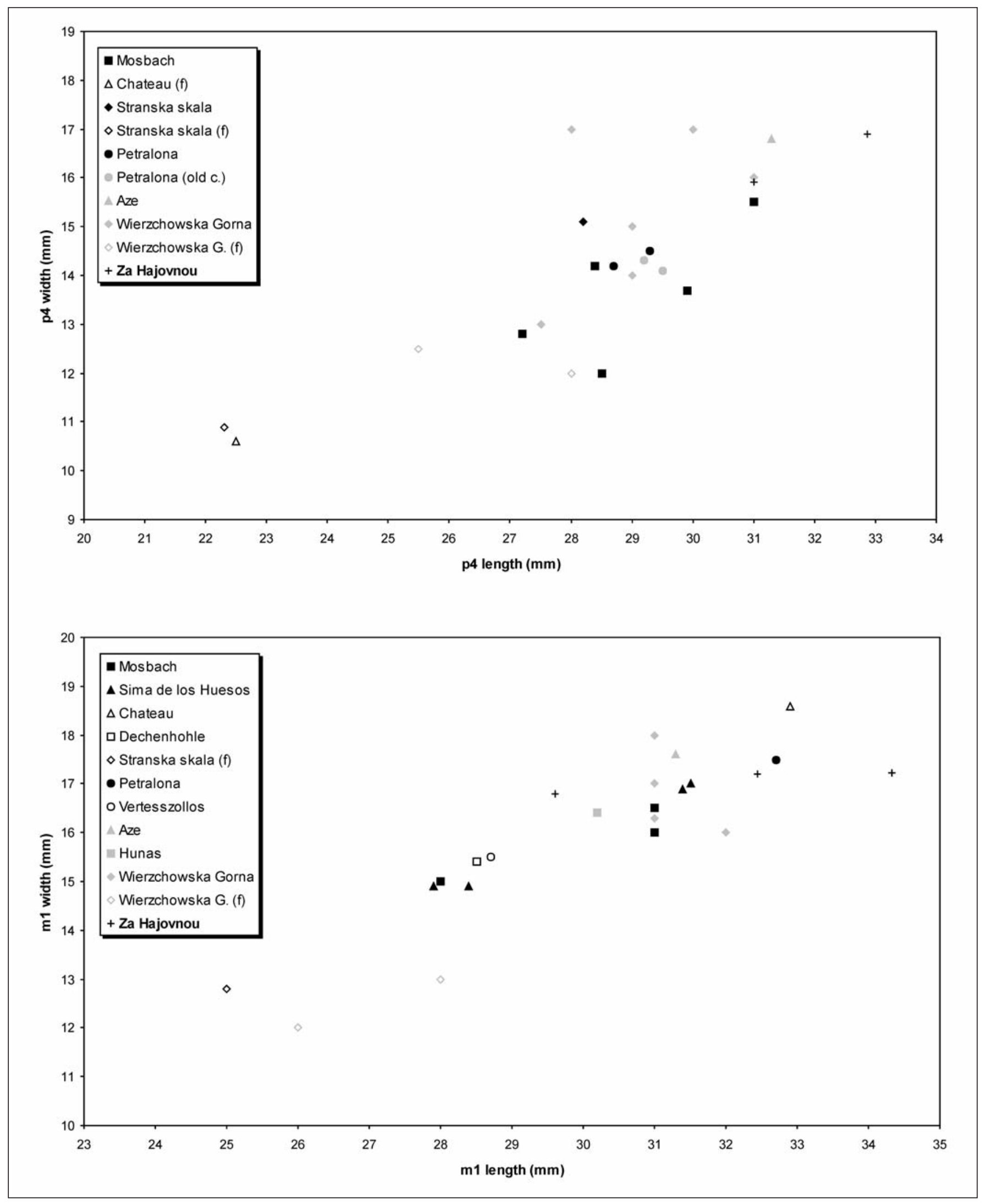

Text-fig. 5. Size comparison of lion $\mathrm{p} 4$ and $\mathrm{m} 1$ from Za Hájovnou Cave with close relative forms from European sites (black: Panthera fossilis, grey: Panthera cf. fossilis or Panthera fossilis - spelaea; $f=$ female, old $c .=$ old collection). Data source: Wojtusiak 1953, Thenius 1972, Schütt and Hemmer 1978, Argant 1988, 1991, García 2003, Baryshnikov and Tsoukala 2010).

cave lions. Since it is impossible to exactly distinguish astragali of $P$. fossilis from these of $P$. spelaea on the basis of morphology, it can not be excluded that the record from
Kostnice II belonged to a smaller specimen (probably female), whereas the remaining two ankle bones could represent male specimens. 
On the contrary, the calcaneus articular facet morphology allows unambiguous distinguishing between cave lions and $P$. leo (see above). The lion-like calcanei from Middle Pleistocene deposits from Za Hájovnou Cave form a "connecting link" between the calcaneal morphotypes of both above mentioned species and sizewise are different from calcanei of cave lions from the Late Pleistocene, coming within the size range for calcanei of $P$. fossilis (cf. Argant 1991: tab. 76). In addition, the found Moravian calcaneal bones show not only certain differences in size, indicating a possible intraspecific variability or sexual dimorphism (two larger specimens and three smaller ones), but also proportional differences - two calcanei are proportionally wider (calcaneus dext. from layer 5 of the Narozeninová chodba and calcaneus sin. from layer 3 of the Chodba naděje) than the remaining three from the Chodba naděje (layer 3), which are distinctly narrower and more slender, but longer than the other two calcaneal bones (Tab. 4). Based on this, it can not be excluded that this phenomenon may reflect certain evolutionary changes(?) in locomotion (or in the function of hindlimbs resp.?) of lion-like felids during the Middle Pleistocene. This character appears to be of importantance and it should be studied further according to the more than adequate amount of well-preserved and stratified finds of calcaneal bones and adjacent elements available for research.

From all the analysed metapodial bones, only Mt IV sin. from the brown loam complex in the Kostnice II is completely preserved. Its measurements indicate a big animal, similar to a specimen from Žernavá (Musil 1969) in size as well as big specimens from the French site of Château (Argant 1991). Mt IV dext. from layer 5 of the Narozeninová chodba could belong to an even more robust specimen (Tab. 4) and also remaining fragments of metapodial bones (Mc I dext., Mc III dext., Mt III sin., and Mt IV sin.) in size exceed the measurements of equivalent metapodials of cave lions from the Last Glacial, or from the Late Pleistocene respectively.

Based on the above mentioned data, the fossils of lion-like felids from the Middle Pleistocene deposits of $\mathrm{Za}$ Hájovnou Cave can be attributed to the species $P$. fossilis (REIChenau, 1906). The fossil remains from the Vykopaná chodba (Profile ZH P-3, layers 3 and 4), the Chodba naděje (Profile ZH P-7b, layers (3)4 and 6), the Kostnice I (Profile ZH P-6, depth to $4 \mathrm{~m}$ ), and the Narozeninová chodba (Profile ZH P-9, layer 5) belong to typical representatives of the species and they are comparable mainly with the fossil record from Château (MIS 13) or Petralona (finds from $\geq$ MIS 11). On the contrary, lion fossils from the Vykopaná chodba (left side), the Chodba naděje (Profile ZH P-7b, layer 3) as well as from the Kostnice II (Profile ZH P-5, layers $2 b$ to $3 b$ and the brown loam complex) probably come from a later period ( $\leq$ MIS 9). They form a group which differs from the former group ( $\geq$ MIS 9) not only in the partly smaller measurements (which, however, still come within the size range for $P$. fossilis), but also by certain morphological and proportional characters (e. g. in p4 or in the calcaneal bones), indicating a trend towards the evolution of characters which are known in lion-like felids from the Saalian Complex or in the Late Pleistocene P. spelaea. The left mandible fragment with $\mathrm{p} 4$ and $\mathrm{m} 1$ from non-stratified finds probably belongs to this group, mainly because of the ratio between the premolar and molar lengths.
$P$. fossilis represents the first immigration wave of lion-like felids in Europe, occurring here as late as MIS 17 (Lewis et al. 2010). According to Baryshnikov and Tsoukala (2010), the species became extinct during the Holsteinian (MIS 9). After this period (MIS 8 - MIS 5), only "intermediate forms" are known from the Old Continent, showing characters of $P$. fossilis as well as $P$. spelaea. These forms have been mentioned for example from the French site of Azé (Argant 1991) or from Polish sites such as Wierzchowska Górna (Barycka 2008) and San (Marciszak et al. 2014), probably representing autochthonous postHolsteinian palaeopopulations with the evolution of characters that are parallel to those of Late Pleistocene cave lions. Cave lions from the Late Pleistocene probably represent an independent lineage (Burger et al. 2004, Barnett et al. 2009), the occurrence of which in (Central and Western) Europe during the Late Pleistocene (especially during the Last Glacial) is a result of an immigration event from the East, comparable with the possible immigration of cave bears of the Ursus ingressus form. The situation is slightly complicated by the second immigration wave of modern lion from Africa, which happened approximately 100000 years ago (Yamaguchi et al. 2004). The representatives of this second migration wave of African lions were present in Europe until 330-100 years BC (Schaller 1980).

\section{Conclusions}

The basic morphometric analysis of fossil remains of lion-like felids $(\mathrm{MNI}=4)$ from Middle Pleistocene deposits ( MIS 9) in Za Hájovnou Cave, excavated during field campaigns between 1987-2007, enabled their taxonomic attribution to the species Panthera fossilis (REICHENAU, 1906). The material under study, however, does not show uniformity in either size or morphologic characters and can be divided into two groups. The first group is represented by fossils found in sediments of the Vykopaná chodba (Profile ZH P-3, layers 3 and 4), the Chodba naděje (Profile ZH P-7b, layers (3)4 and 6), the Kostnice I (Profile ZH P-6, to a depth $4 \mathrm{~m}$ ), and the Narozeninová chodba (Profile ZH P-9, layer 5), probably deposited during the period of MIS 9 and/or earlier ( $\geq$ MIS 9). This is supported by the morphologic and size characters of fossil remains from sites in western and southern Europe which are more typical for $P$. fossilis specimens from the period before MIS 9. Fossils showing more advanced characters mentioned in connections with lion remains from the Saalian Complex (so called "intermediate forms") to the Late Pleistocene ( $P$. spelaea), are included within the second group. These fossils were found mainly in sediments of the Vykopaná chodba (left side), the Chodba naděje (Profile ZH P-7b, layer 3) as well as of the Kostnice II (Profile ZH P-5, layers 2b to 3b and the brown loam complex). According to Lundberg et al. (2014), these were deposited partly during MIS 9 or later ( $\leq$ MIS 9 ). So far, difficultly has been experienced in evaluating the level of the evolutionary process within the fossilis - spelaea lineage at the site since only part of the fossils have been analysed. In addition, the results obtained can not be assessed statistically. A possibility that the so called "intermediate forms" of lion-like felids from the late Middle Pleistocene 
(Saalian Complex) and from the beginning of the Late Pleistocene (Eemian Interglacial) represent only autochthonous palaeopopulations of descendants of pre-Holsteinian P. fossilis can not be excluded. Some advanced characters of these "intermediate forms" could have evolved parallely with similar features in cave lion lineage ( $P$. spelaea), maybe representing only an eastern immigration element within the fauna of Central and Western Europe during the Last Glacial (Weichselian).

\section{Acknowledgements}

The author would like to sincerely thank to Professor Emeritus Rudolf Musil from Masaryk University in Brno for the possibility to participate in research at the site and its fossil record, to Dr. Martina Roblíčková for access to the palaeovertebratological collections of the Moravian Land Museum - Anthropos Museum for scientific use, as well as to all friends from Moravia and Bohemia for their help. He also gratefully acknowledges the helpful comments and suggestions of the anonymous reviewers. His thanks also goes to Gill Horalek for English correction. The research for this paper was carried out with financial support from the Scientific Grant Agency of the Ministry of Education of the Slovak Republic (contract under VEGA No. 1/0396/12).

\section{References}

Ábelová, M. (2005): Doprovodná fauna vel'kých cicavcov medvedej jaskyne „Za Hájovnou“, Javoříčsky kras [Accompanying Fauna of Large Mammals in "Za Hájovnou" Caev (Javoříčko Karst, Moravia)]. - Př́rodovědné studie Muzea Prostějovska, 8: 171-184. (in Slovak)

Argant, A. (1988): Etude de 1'exemplaire de Panthera spelaea (Goldfuss, 1810) (Mammalia, Carnivora, Felidae) du gisement Pleistocene moyen recent de la grotte d'Aze (Saone et Loire) [Study of Panthera spelaea (Goldfuss, 1810) specimen (Mammalia, Carnivora, Felidae) from Middle Pleistocene deposits of Azé Cave (Saone et Loire)]. - Revue de Paléobiologie, 7(2): 449-466. (in French)

Argant, A. (1991): Carnivores quaternaires de Bourgogne [Quaternary carnivores of Bourgogne]. - Documents des Laboratoires de Géologie, 115: 1-304. (in French)

Argant, A., Argant, J., Jeannet, M., Erbajeva, M. (2007): The big cats of the fossil site Château Breccia Northern Section (Saône-et-Loire, Burgundy, France): stratigraphy, palaeoenvironment, ethology and biochronological dating. - In: Kahlke, R.-D., Maul, L. C., Mazza, P. P. A. (eds), Late neogene and quaternary biodiversity and evolution: Regional developments and interregional correlations. Proceedings of the $18^{\text {th }}$ International Senckenberg Conference (VI International Palaeontological Colloquium in Weimar), Volume II. Courier Forschungsinstitut Senckenberg, 259: 121-140.

Ballesio, R. (1980): Le gissement pléistocéne supérieur de la grotte Jaurens a Nespouls, Corrézè France: Les Carnivores (Mammalia, Carnivora) II. Felidae [Distribution of Pleistocene in caves of Jaurens and Nespouls, Corrézè France: Carnivores (Mammalia, Carnivora) II. Felidae]. Nouv. Arch. Hist. nat. Lyon, 18: 61-102. (in French)
Barnett R., Shapiro B., Barnes I., Ho S. Y. W., Burger J., Yamaguchi N., Higham T. F. G., Wheeler H. T., Rosendahl W., Sher A. V., Sotnikova M., Kuznetsova T., Baryshnikov G. F., Martin L. D., Harington C. R., Burns J. A., Cooper A. (2009): Phylogeography of lions (Panthera leo ssp.) reveals three distinct taxa and a late Pleistocene reduction in genetic diversity. - Molecular Ecology, 18: 1668-1677. http://dx.doi.org/10.1111/j.1365-294X.2009.04134.x

Barycka, E. (2008): Fauna Poloniae-Fauna Polski. Vol. 2ns - Middle and late Pleistocene Felidae and Hyaenidae of Poland. - Natura optima dux Foundation, Museum and Istitute of Zoology Polish Academy of Science, Warszawa, $228 \mathrm{pp}$..

Baryshnikov, G., Boeskorov, G. (2001): The Pleistocene cave lion, Panthera spelaea (Carnivora, Mammalia) from Yakutia, Russia. - Cranium, 18(1): 7-23.

Baryshnikov, G. F., Tsoukala, E. (2010): New analysis of the Pleistocene carnivores from Petralona Cave (Macedonia, Greece) based on the Collection of the Thessaloniki Aristotle University. - Geobios, 43: 389-402. http://dx.doi.org/10.1016/j.geobios.2010.01.003

Bona, F. (2006): Systematic position of a complete lion-like cat skull from the Eemian ossiferous rubble near Zandobbio (Bergamo, north Italy). - Rivista Italiana di Paleontologia e Stratigrafia, 112(1): 157-166.

Bonifay M.-F. (1971): Carnivores Quaternaires du Sud-Est de la France [Quaternary carnivores from SE of France]. - Mémoires de Muséum national d'Histoire Naturelle, Nouvelle série, C, 21: 43-377. (in French)

Burger J., Rosendahl W., Loreille O., Hemmer H., Eriksson T., Götherström A., Hiller J., Collins M. J., Wess T., Alt K. W. (2004): Molecular phylogeny of the extinct cave lion Panthera leo spelaea. - Molecular Phylogenetics and Evolution, 30: 841-849. http://dx.doi.org/10.1016/j.ympev.2003.07.020

Christiansen, P., Harris, J. M., (2009): Craniomandibular morphology and phylogenetic affinities of Panthera atrox: Implications for the evolution and paleobiology of the lion lineage. - Journal of Vertebrate Paleontology, 29(3): 934-945. http://dx.doi.org/10.1671/039.029.0314

Dietrich, W. O. (1968): Fossile Löwen im europäischen und afrikanischen Pleistozän [Fossil lions in European and African Pleistocene]. - Paläontologische Abhandlungen, Abteilung A - Paläozoologie, 3(2): 324-366. (in German)

García, N. G. (2003): Osos y otros carnívoros de la Sierra de Atapuerca [Bears and other carnivores from the Atapuerca Mountain]. - Fundación Oso de Asturias, Asturia, Proaza, 576 pp. (in Spanish)

Gonzáles, F. L. (2003): Paleontology and taphonomy of Pleistocene macromammals of Galicia (NW Iberian Penninsula). - Nova Terra, 22: 1-264.

Hankó, E. P. (2007): A revision of three Pleistocene subspecies of Panthera, based on mandible and teeth remains, stored in Hungarian collections. - Fragmenta Palaeontologica Hungarica, 24-25: 25-43.

Hemmer, H. (1974): Untersuchungen zur Stammesgeschichte der Pantherkatze (Pantherinae), Teil III: Zur Artgeschichte des Löwen Panthera (Panthera) leo (Linnaeus, 1758) [Phylogenetic study of pantherine cats (Pantherinae), Part III: Species history of the lion 
Panthera (Panthera) leo (Linnaeus, 1758)]. Veröffentlichungen der Zoologischen Staatssammlung München, 17: 167-280. (in German)

Hemmer, H., Kahlke, R.-D., Vekua, A. K. (2001): The jaguar - Panthera onca gombaszoegensis (Kretzoi, 1938) (Carnivora: Felidae) in the late Lower Pleistocene of Akhalkalaki (South Georgia; Transcaucasia) and its evolutionary and ecological significance. - Géobios, 34 : 475-486. http://dx.doi.org/10.1016/S0016-6995(01)80011-5

Hemmer, H., Schütt, G. (1969): Ein Unterkiefer von Panthera gombaszoegensis (Kretzoi, 1938) aus den Mosbacher Sanden [A mandible of Panthera gombaszoegensis (Kretzoi, 1938) from Mosbach Sands]. - Mz. Naturw. Arch., 8: 90-101. (in German)

Kabitzsch, J.-F. (1960): Die Verwandtschaft vom Löwen und Tiger dargestellin ihrem gebiss unter Berücksichtigung der Gebisse von Jaguar und den zwei pleistozänen Großkatzen Felis spelaea und Felis atrox [Relation between lion and tiger in the light of their dentition within the comparison with dentition of jaguar and two Pleistocene big cats Felis atrox and Felis spelaea]. Säugetierkundliche Mitteilungen, 8: 103-140. (in German)

Kurtén, B. (1965): The Pleistocene Felidae of Florida. Bulletin of Florida State Museum, 9 (6): 215-273.

Lehmann, U. (1954): Die Fauna des „Vogelherds“ bei Stetten ob Lontal (Württemberg) [Fauna of „Vogelherds“ near Stetten or Lontal (Württemberg)]. - Neues Jahrbuch für Geologie und Paläontologie, Abh., 99(1): 33-146. (in German)

Lewis, M., Pacher, M., Turner, A. (2010): The larger Carnivora of the West Runton Freshwater Bed. Quaternary International, 228: 116-135. http://dx.doi.org/10.1016/j.quaint.2010.06.022

Lundberg, J., Musil, R., Sabol, M. (2014): Sedimentary history of Za Hájovnou Cave (Moravia, Czech Republic): A unique Middle Pleistocene palaeontological site. Quaternary International, 339-340: 11-24. http://dx.doi.org/10.1016/j.quaint.2013.04.006

Marciszak, A., Schouwenburg, Ch., Darga, R. (2014): Decreasing size process in the cave (Pleistocene) lion Panthera spelaea (Goldfuss, 1810) evolution - A review. - Quaternary International, 339-340: 245-257. http://dx.doi.org/10.1016/j.quaint.2013.10.008

Maul, L. C., Heinrich, W.-D., Parfitt, S. A., Paunescu, A.-C. (2007): Comment on the correlation between magnetostratigraphy and the evolution of Microtus (Arvicolidae, Rodentia, Mammalia) during the Early and early Middle Pleistocene. - In: Kahlke, R.-D., Maul, L. C., Mazza P. P. A. (eds.), Late neogene and quaternary biodiversity and evolution: Regional developments and interregional correlations. Proceedings of the $18^{\text {th }}$ International Senckenberg Conference (VI International Palaeontological Colloquium in Weimar), Volume II. Courier Forschungsinstitut Senckenberg, 259: 243-263.

Musil, R. (1969): Eine karstspalte mit mittelpleistozänen Funden im Kalksteinbruch Žernavá [Karst fissure with Middle Pleistocene finds in the limestone quarry of Žernavá]. - Časopis moravského musea - Acta Musei Moraviae, Vědy prŕrodní - Scientiae naturales, 54: 85-96. (in German)
Oken, L. (1816): Okens Lehrbuch der Naturgeschichte [Oken's Textbook of Natural History], Thl. III Zoologie, Abth. 2 Fleischthiere. - August Schmid und Comp., Jena, xvi+1270 pp. (in German)

Reichenau, W. von (1906): Beiträge zur näheren Kenntnis der Carnivoren aus den Sanden von Mauer und Mosbach [Contribution to knowledge of carnivores from sands of Mauer and Mosbach]. - Abh. Großherzogl. Hess. Geol. Landesanst., 4: 189-313. (in German)

Sala, B. (1990): Panthera leo fossilis (v. ReICHENAU, 1906) (Felidae) de Isernia la Pineta (Pléistocène moyen inférieur d'Italie) [Panthera leo fossilis (v. ReICHenau, 1906) (Felidae) from Isernia la Pineta (early Middle Pleistocene, Italy]. - Geobios, 23(2): 189-194. (in French) http://dx.doi.org/10.1016/S0016-6995(06)80051-3

Schaller, G. B. (1980): Zlaté stíny, pádící kopyta [Golden shadows, Flying hooves]. - Mladá fronta, Praha, 272 pp. (in Czech)

Schütt, G. (1969): Untersuchungen am Gebiss von Panthera leo fossilis (v. Reichenau, 1906) und Panthera leo spelaea (Goldfuss, 1810) [Study on the dentition of Panthera leo fossilis (v. Reichenau, 1906) and Panthera leo spelaea (Goldfuss, 1810)]. - Neues Jahrbuch für Geologie und Paläontologie, Abh., 134(2): 192-220. (in German)

Schütt, G., Hemmer, H. (1978): Zur Evolution des Löwen (Panthera leo L.) im europäischen Pleistozän [Evolution of lions (Panthera leo L.) in European Pleistocene]. Neues Jahrbuch für Geologie und Paläontologie, Mh., (4): 228-255. (in German)

Sotnikova, M., Nikolskyi, P. (2006): Systematic position of the cave lion Panthera spelaea (Goldfuss) based on cranial and dental characters. - Quaternary International, 142-143: 218-228. http://dx.doi.org/10.1016/j.quaint.2005.03.019

Thenius, E. (1972): Die Feliden (Carnivora) aus dem Pleistozän von Stránská skála [Felids (Carnivora) from the Pleistocene of Stránska skála]. - In: Musil, R. (ed.): Stránská skála I 1910-1945. Studia Musei Moraviae Anthropos, 20(N. S. 12): 121-135. (in German)

Vereshchagin, N. K. (1971): Peshcherniy lev i ego istoria v Golarktike i v predelakh SSSR [Cave lion and its history in Holarctic and in the terrirory of USSR]. - Trudy Zoologičeskogo instituta, 49: 123-199. (in Russian)

Wojtusiak, K. (1953): Szczątki lwa jaskiniowego (Felis spelaea Goldf.) z jaskini «Wierzchowskiej Górnej» [Remains of cave lion (Felis spelaea Goldf.) from Wierzchowska Górna Cave]. - Acta Geologica Polonica, 3: 573-592. (in Polish)

Wurm, A. (1912): Beiträge zur Kenntnis der diluvialen Säugetierfauna von Mauer a. d. Elsenz (bei Heidelberg). I. Felis leo fossilis [Contribution to the knowledge of diluvial fauna of mammals from Mauer a. d. Elsenz (near Heidelberg). I. Felis leo fossilis]. - Jahres-Berichte und Mitteilungen des Oberrheinischen geologischen Vereines, Neue Folge, 2: 77-102. (in German)

Yamaguchi, N., Cooper, A., Werdelin, L., Macdonald, D. W. (2004): Evolution of the mane and group-living in the lion (Panthera leo): a review. - Journal of the Zoological Society of London, 263: 329-342.

http://dx.doi.org/10.1017/S0952836904005242 